\title{
Preservative effect of lupine extract (Lupinus luteus) on quality of raw cow's milk during storage
}

\author{
ABDELAZIZ MUSA MOHAMMED MOHAMMED ${ }^{1}$, OMER IBRAHIM AHMED HAMID ${ }^{2, \bullet}$ \\ ${ }^{1}$ College of Graduate Studies, Sudan University of Sciences and Technology, Khartoum, Sudan \\ ${ }^{2}$ Department of Dairy Science and Technology, College of Animal Production Science and Technology, Sudan University of Science and Technology, \\ Khartoum, Sudan. `email: omerhi30@yahoo.com
}

Manuscript received: 17 September 2016. Revision accepted: 11 March 2017.

\begin{abstract}
Mohammed AMM, Hamid OIA. 2017. Preservative effect of lupine extract (Lupinus luteus) on quality of raw cow's milk during storage. Biofarmasi J Nat Prod Biochem 15: 45-52. The experiment was conducted to assess the effect of various levels of lupine (Lupinus luteus) extract as milk preservative on the physicochemical and microbial load of raw cow's milk in 2016. The milk samples were purchased from a milk dairy farm of the College of Animal Production Science and Technology, Sudan University of Science and Technology in the Kuku area. Five treatments were carried out in this study; in the first treatment, raw cow's milk was left at room temperature without lupine extract, and, respectively, in $2^{\text {nd }}, 3^{\text {rd }}, 4^{\text {th }}$ and $5^{\text {th }}$ treatments, $0.5 \%, 1 \%, 1.5 \%$, and $2 \%$ of lupine extract were added to fresh milk samples (four hundred mls of milk for each sample). The raw milk samples in all treatments were left for $0,1,2,3$, 4, and 5 hours at room temperature. The milk samples' physicochemical (protein, fat, titratable acidity, total solids not fat, $\mathrm{pH}$ and ash) and microbiological (total bacteria count) analyses were taken. The results showed that the lupine extract significantly $(\mathrm{p}<0.05)$ affected the milk samples' protein, fat, total solids, not fat, and $\mathrm{pH}$ contents. At the same time, no significant $(\mathrm{P} \geq 0.05)$ effect was found in raw milk samples' acidity and ash contents. The storage period significantly $(\mathrm{p}<0.05)$ affected the fat, $\mathrm{pH}$, and acidity of raw milk samples, while no significant effect was reported in the protein, total solids, not fat, and ash contents. The microbial load of raw milk (Total bacterial count) was significantly $(\mathrm{p}<0.05)$ affected by the increased level of lupines. The storage period significantly $(\mathrm{p}<0.05)$ affected the microbial load of the fresh milk.
\end{abstract}

Keywords: cow's milk, lupine extract, Lupinus luteus, quality, storage

\section{INTRODUCTION}

Preserving raw milk samples is common in numerous nations since the demonstrative research facilities are far from most dairy farming communities; transport of the samples to the research facility for analysis is inadequate (Dunham, 1985). These issues are aggravated by the requirement for facilities to keep the milk cool to minimize bacterial proliferation and sample spoilage before the examination. Nowadays, scientists have used various milk preservatives (hydrogen peroxide, sodium azide, bronopol, potassium dichromate, boric acid, milkofix, azidiol, and ortobor acid) to overcome these problems ( $\mathrm{Ng}$ and Hayes 1982; Hanus et al. 1992a,b; Heeschen et al. 1994; Saha et al. 2003; FOSS Electric 2005). Applying an instrumental method in analyzing raw milk and using preservative agents is allowed (FOSS Electric 2005). The literature makes it possible to find various preservatives for each indicator (total bacteria count, fat and protein content, somatic cell count) (Seškēena and Jankevica 2007).

To optimize the instrumental method and exact estimation of milk content and quality markers, it is fundamental to discover an additive that could be utilized to appraise all of the markers from one test vial until the final one. In Sudan, it is common practice to utilize lupine seeds as an additive by wrapping them into a piece of clean cloth and inserting it into the fresh raw milk container while buying the milking process. The reason for the importance of this study is to know the possibility of using the extract of a lupine (Lupinus luteus L.) as an additive figure on the physicochemical and microbial degree of raw milk.

The objective of the study was: (i) To study the physicochemical properties of raw cow's milk with various levels of lupine extract; (ii) To determine the microbial load of raw cow's milk with various levels of lupine extract, (iii) To determine the shelf life of raw cow's milk with various level of lupine extract during storage.

\section{MATERIALS AND METHODS}

The study was conducted in 2016 at the College of Animal Production Sciences and Technology laboratories, Sudan University of Sciences and Technology, Khartoum, Sudan.

\section{Materials}

Source of milk

Six liters of fresh cow's milk were purchased from the College of Animal Production Sciences and Technology, Sudan University of Sciences and Technology Dairy farm in the Kuku area. 
Source of lupine:

Lupine seeds were bought at the Kuku market in the Khartoum State of Sudan.

\section{Methods}

Lupine extracts preparation

The lupine seeds were ground into a fine powder (flour) before being added to a hundred $\mathrm{mLs}$ of distilled water in various lupine powder weights; they were sterilized at 55 ${ }^{\circ} \mathrm{C}$ for twenty-four hours (24) hrs. Then, $0.5 \%, 1 \%, 1.5 \%$, and $2 \%$ of the total weight of the flour were soaked in distilled water and kept at the refrigerator temperature for $24 \mathrm{hrs}$; then, they were filtered by filter papers (size 42).

\section{Treatments}

In this study, five treatments were implemented. First was the control, in which a sample of raw fresh cow milk was left at room temperature without lupine extract addition. In contrast, in the second, third, fourth, and fifth treatments, respectively, $0.5 \%, 1 \%, 1.5 \%$, and $2 \%$ of lupine extract were added to the raw cow's milk (four hundred mLs of milk for each sample) samples. The raw milk samples in all treatments were left for $0,1,2,3,4$, and 5 hours at room temperature. The milk samples' physicochemical analysis was carried out to analyze the content of protein, fat, titratable acidity, total solids, non fat, $\mathrm{pH}$ and ash at each specified time. Each treatment was repeated three times.

\section{Chemical analysis of milk}

The chemical composition of milk and treatment samples (protein, fat, total solids, not fat, and $\mathrm{PH}$ ) was determined by Lactoskan (made in BULGARIA, SUPPLY 12-14V DC50W) (a fresh milk analyzer). In contrast, the titratable acidity and ash were determined by AOAC (2009) methods.

\section{Ash content}

The ash content was determined in accordance with AOAC (2009). $10 \mathrm{~mL}$ of milk were weighed and poured into a suitable clean, dry container and evaporated to dry on the steam bath, and the container was placed in muffle fume at $55^{\circ} \mathrm{C}$ for $1.5-2 \mathrm{hrs}$, cooled in dissector, and weighed. The following formula calculated the ash content:

$\mathrm{Ash} \%=\mathrm{w} 1 / \mathrm{w} 0 \mathrm{X} 100$

Where:=

w1 : weight of ash

w0 : weight of sample.

\section{Titratable acidity}

Titratable acidity was decided in line with AOAC (2009). Ten mills of milk samples were put into a clean porcelain dish, and three to five drops of phenolphthalein marker were added; the sample was titrated against 0.1 $\mathrm{NaOH}$ until a faint color lasted for at least 30 seconds, then the titratable acidity of each sample was calculated with the following formula:
Titratable acidity $=\mathrm{T} / \mathrm{W}$

Where:

$\mathrm{T}$ : Titration figures

$\mathrm{W}:$ Weight of samples

\section{Microbial analysis (total bacteria count)}

The agar plate medium was used for the determination of the total bacteria count, according to Ramakant (2006).

The preparation of Nutrient Agar (the medium). The manufacturer's instructions were followed, namely, first, dissolving 28 grams of powder of agar plate medium in one liter of distilled water, second, boiling it and sterilizing it in an autoclave at $121^{\circ} \mathrm{C}$ for fifteen minutes.

Culturing. Serial dilutions were made for each sample, then from each dilution, fifty micro-milliliters $(\mathrm{mmL})$ were transferred into sterile Petri dishes (duplicate), followed by the addition of melted, cooled $\left(45-46^{\circ} \mathrm{C}\right)$ plate count agar and mixed them thoroughly by rotating it, firstly, in one direction, and secondly, in the opposite direction. When the medium had solidified, the dishes were incubated in an inverted position at $37^{\circ} \mathrm{C}$ for 24 hours.

Counting. The quantity of colony-forming units (CFU) in each dilution was obtained by multiplying the quantity of colonies in the reciprocal to each dilution.

\section{Statistical analysis}

Statistical analysis was done using Statistical Package for Social Science (SPSS, version 16. 2007). General linear models were used to assess the impact of various levels of lupine concentrate, stockpiling periods, and the interaction between the various levels on the crude cow's chemical composition and microbial load. The least significant difference (LSD) was used to separate the treatment's mean. The level of significance $(0.05)$ was used in this study.

\section{RESULTS AND DISCUSSION}

\section{Results}

Effect of various levels of the lupine extract on the chemical composition of fresh cow's milk

Results in Table 1 illustrate the effect of various levels of the lupine extract on the physicochemical characteristics of cow milk. The results indicated a significant difference $(p<0.05)$ in the protein content of the treatments.

The data showed that the highest protein content $(3.24 \pm 0.22 \%)$ was in control milk sample, while the lowest $(3.02 \pm 0.17 \%)$ was recorded in the cow's milk treated with $0.5 \%$ lupine extract.

The fat content of the fresh milk sample was significantly $(\mathrm{p}<0.05)$ highest $(4.04 \pm 0.76 \%)$, while the lowest value $(3.35 \pm 0.21 \%)$ was found in the milk treated with $1 \%$ lupine extract (Table 1).

The results in Table 1) indicated that Total Solids Not Fat was significantly different $(\mathrm{p}<0.05)$ within the treatments. The control milk sample had a higher TSNF content $(8.78 \pm 0.64 \%)$. However, a lower fat value $(8.27 \pm 0.46 \%)$ was found in the milk treated with $0.5 \%$ lupine extract. $\mathrm{pH}$ content was significantly $(\mathrm{p}<0.05)$ 
affected by various levels of lupine extract within all treatments. The lowest $\mathrm{pH}$ level $(6.73 \pm 0.11)$ was scored by the milk with $0.5 \%$ lupine extract, while the highest one $(7.01 \pm 0.36)$ was scored by the milk treated with zero lupine extract (Table 1).

The acidity of the cow milk samples was not significantly $(\mathrm{p}<0.05)$ affected by the treatments. Highest acidity percent $(0.22 \pm 0.01)$ was for the control, treatment with $1.5 \%$ lupine extract, and $2 \%$ lupine extract, while the lowest value $(0.21 \pm 0.02 \%)$ was for treatment with $0.5 \%$ and $1 \%$ lupine extract (Table 1).

The ash data in Table 1) showed that ash content was not significantly $(p<0.05)$ affected by the concentration of lupine extract. The highest ash content $(0.67 \pm 0.08 \%)$ was found in treatment with $0.5 \%$ and $1.5 \%$ lupine extract; however, the lowest value $(0.63 \pm 0.19 \%)$ was recorded on control milk samples.

Effect of storage period on physicochemical characteristics of fresh cow's milk

Data in Table 2 showed the effect of storage time on the physicochemical characteristics of the fresh cow's milk. The result indicated that the storage time had a significant $(p<0.05)$ effect on the acidity content of the fresh cow's milk (Table 2$)$. The highest acidity content $(0.23 \pm 0.01 \%)$ was at four hours of storage, and the lowest value $(0.21 \pm 0.01 \%)$ was under control. The data indicated that the storage time had significantly $(\mathrm{p}<0.05)$ affected the fat content. The highest fat content $(3.84 \pm 1.07 \%)$ was found at zero hour storage. The lowest one $(3.23 \pm 0.26 \%)$ was reported at five hours of storage (Table 2).

The study demonstrated that (Table 2) the storage time had significantly $(p<0.05)$ affected the T.S.N.F content. The highest T.S.N.F content $(8.59 \pm 0.33)$ was recorded at two hours of storage, while the lowest $(8.26 \pm 0.26)$ was found at five hours. Statistical analysis revealed that storage time had no significant $(\mathrm{p}<0.05)$ effect on ash content, total solids, not fat, and the fresh cow milk protein content samples (Table 2).

\section{Effect of various levels of lupine extract and storage time} on the physicochemical characteristics of fresh cow's milk The protein content of fresh milk was not significantly $(\mathrm{p}<0.05)$ affected by the level of lupine extract and storage time. The lowest protein content $(2.85 \pm 0.30 \%)$ was observed at zero hour storage in the milk added with $0.5 \%$ lupine extract, while the highest one $(3.56 \pm 0.25 \%)$ was reported at zero hours storage in the control milk sample (Table 3)

Results in Table 4 showed that fat content was significantly $(\mathrm{p}<0.05)$ affected by the level of lupine extract and storage time. The lowest fat content $(2.99 \pm 0.09 \%)$ was recorded at five hours of storage in the milk samples with $0.5 \%$ lupine extract. And the highest one $(5.80 \pm 0.04 \%)$ was found at zero hours of storage in the milk sample with $0.5 \%$ lupine extract.

The total solids not fat content of the milk samples was not significantly $(\mathrm{p}<0.05)$ affected by the level of lupine extract and storage time. The control milk's highest T.N.F content $(9.73 \pm 0.69 \%)$ was at zero hours of storage. While the lowest one $(7.86 \pm 0.74 \%)$ was in milk with $0.5 \%$ lupine extract (Table 5).

Data in Table 6 shows the milk samples' $\mathrm{pH}$ content, which was significantly $(\mathrm{p}<0.05)$ affected by the various level of lupine extract and storage time. The lowest $\mathrm{pH}$ $(6.57 \pm 0.02)$ was reported at five hours of storage in the milk with zero lupine extract, while the highest $(7.53 \pm 0.60)$ was in the milk with $0.5 \%$ lupine extract and stored for one hour.

Table 1. Effect of various levels of the lupine extract on the physicochemical composition of fresh cow's milk

\begin{tabular}{|c|c|c|c|c|c|c|}
\hline \multirow{2}{*}{ Treatment } & \multicolumn{6}{|c|}{ Chemical composition } \\
\hline & Protein\% & Fat $\%$ & T.S.N.F & pH & Acidity & Ash\% \\
\hline Control & $3.24 \pm 0.22 \mathrm{a}$ & $4.04 \pm 0.76 \mathrm{a}$ & $8.78 \pm 0.64 a$ & $6.73 \pm 0.11 \mathrm{c}$ & $0.22 \pm 0.01$ & $0.63 \pm 0.19$ \\
\hline $0.5 \%$ & $3.02 \pm 0.17 \mathrm{c}$ & $3.64 \pm 1.08 \mathrm{~b}$ & $8.27 \pm 0.46 b$ & $7.01 \pm 0.36 \mathrm{a}$ & $0.21 \pm 0.02$ & $0.67 \pm 0.08$ \\
\hline $1 \%$ & $3.02 \pm 0.10 b c$ & $3.35 \pm 0.21 \mathrm{c}$ & $8.29 \pm 0.26 b$ & $6.83 \pm 0.12 b$ & $0.21 \pm 0.01$ & $0.66 \pm 0.11$ \\
\hline $1.5 \%$ & $3.13 \pm 0.15 b$ & $3.41 \pm 0.26 b c$ & $8.53 \pm 0.40 \mathrm{ab}$ & $6.82 \pm 0.09 b c$ & $0.22 \pm 0.01$ & $0.67 \pm 0.08$ \\
\hline $2 \%$ & $3.08 \pm 0.10 b c$ & $3.45 \pm 0.29 b c$ & $8.51 \pm 0.31 \mathrm{ab}$ & $6.79 \pm 0.07 \mathrm{bc}$ & $0.22 \pm 0.02$ & $0.66 \pm 0.09$ \\
\hline Sig & $* *$ & $* *$ & $*$ & $* *$ & N.S & N.S \\
\hline
\end{tabular}

Note: Mean values bearing different superscripts within columns are significantly different $(\mathrm{p}<0.05)$. L.S $=$ level of significance. $*$ NS $=$ not significance

Table 2. Effect of storage period on the physicochemical characteristic of fresh cow milk

\begin{tabular}{|c|c|c|c|c|c|c|}
\hline \multirow{2}{*}{ Storage time } & \multicolumn{6}{|c|}{ Chemical composition } \\
\hline & Protein\% & Fat $\%$ & T.S.N.F & $\mathbf{p H}$ & Acidity & Ash\% \\
\hline Zero hour & $3.11 \pm 0.29 \mathrm{ac}$ & $3.84 \pm 1.07 \mathrm{a}$ & $8.54 \pm 0.77$ & $6.78 \pm 0.05 b c$ & $0.21 \pm 0.01 b$ & $0.69 \pm 0.10 \mathrm{a}$ \\
\hline $1 \mathrm{hr}$ & $3.06 \pm 0.13 \mathrm{ac}$ & $3.47 \pm 0.34 b c$ & $8.38 \pm 0.35$ & $6.96 \pm 0.36 \mathrm{a}$ & $0.21 \pm 0.00 \mathrm{~b}$ & $0.67 \pm 0.09 \mathrm{ab}$ \\
\hline $2 \mathrm{hrs}$ & $3.15 \pm 0.12 \mathrm{ab}$ & $3.69 \pm 0.75 \mathrm{ab}$ & $8.59 \pm 0.33$ & $6.88 \pm 0.07 \mathrm{ab}$ & $0.210 .01 \mathrm{~b}$ & $0.60 \pm 0.18 \mathrm{ab}$ \\
\hline $3 \mathrm{hrs}$ & $3.13 \pm 0.19 \mathrm{a}$ & $3.64 \pm 0.66 \mathrm{ab}$ & $8.50 \pm 0.54$ & $6.98 \pm 0.17 \mathrm{a}$ & $0.21 \pm 0.01 b$ & $0.58 \pm 0.06 b$ \\
\hline $4 \mathrm{hrs}$ & $3.00 \pm 0.12 \mathrm{c}$ & $3.61 \pm 0.46 a b$ & $8.26 \pm 0.35$ & $6.76 \pm 0.08 \mathrm{ac}$ & $0.23 \pm 0.01 \mathrm{a}$ & $0.70 \pm 0.09 \mathrm{a}$ \\
\hline $5 \mathrm{hrs}$ & $3.14 \pm 0.08 \mathrm{a}$ & $3.23 \pm 0.26 \mathrm{c}$ & $8.58 \pm 0.23$ & $6.67 \pm 0.06 c$ & $0.23 \pm 0.02 \mathrm{a}$ & $0.69 \pm 0.07 \mathrm{a}$ \\
\hline Sig & NS & $* *$ & NS & $* * *$ & $* * *$ & NS \\
\hline
\end{tabular}

Note: Mean values bearing different superscripts within columns are significantly different $(\mathrm{p}<0.05)$. L.S $=$ levels of significance. $*$ NS $=$ not significance 
Table 3. Effect of various levels of lupine extracts and storage time on the protein of fresh milk

\begin{tabular}{|c|c|c|c|c|c|}
\hline \multirow{2}{*}{ Storage time } & \multicolumn{5}{|c|}{ Lupine concentration } \\
\hline & Control & $0.5 \%$ & $1 \%$ & $1.5 \%$ & $2 \%$ \\
\hline Zero hour & $3.56 \pm 0.25$ & $2.85 \pm 0.30$ & $2.97 \pm 0.01$ & $3.02 \pm 0.04$ & $3.17 \pm 0.11$ \\
\hline $1 \mathrm{hr}$ & $3.26 \pm 0.07$ & $2.99 \pm 0.04$ & $2.99 \pm 0.05$ & $3.11 \pm 0.11$ & $2.96 \pm 0.03$ \\
\hline $2 \mathrm{hrs}$ & $3.10 \pm 0.29$ & $3.25 \pm 0.07$ & $3.14 \pm 0.08$ & $3.17 \pm 0.04$ & $3.12 \pm 0.01$ \\
\hline $3 \mathrm{hrs}$ & $3.27 \pm 0.04$ & $2.90 \pm 0.07$ & $3.17 \pm 0.04$ & $3.32 \pm 0.25$ & $3.01 \pm 0.04$ \\
\hline $4 \mathrm{hrs}$ & $3.11 \pm 0.27$ & $3.02 \pm 0.09$ & $2.89 \pm 0.00$ & $2.99 \pm 0.04$ & $3.01 \pm 0.01$ \\
\hline $5 \mathrm{hrs}$ & $3.15 \pm 0.12$ & $3.13 \pm 0.00$ & $3.03 \pm 0.01$ & $3.19 \pm 0.05$ & $3.20 \pm 0.09$ \\
\hline
\end{tabular}

Note: Mean values bearing different superscripts within rows are significantly different $<0.05) . *$ L.S $=$ levels of significance. $*$ NS $=$ not significance.

Table 4. Interaction between the various levels of lupine extract and storage time on fat content $(\%)$ of fresh cow's milk

\begin{tabular}{lccccc}
\hline Storage time & Control & $\mathbf{0 . 5 \%}$ & $\begin{array}{c}\text { Lupine concentration } \\
\mathbf{1 \%}\end{array}$ & $\mathbf{1 . 5 \%}$ & $\mathbf{2 \%}$ \\
\hline Zero hour & $3.20 \pm 0.69$ & $5.80 \pm 0.04$ & $3.13 \pm 0.04$ & $3.49 \pm 0.11$ & $3.59 \pm 0.13$ \\
$1 \mathrm{hr}$ & $3.56 \pm 0.33$ & $3.03 \pm 0.05$ & $3.28 \pm 0.07$ & $3.59 \pm 0.16$ & $3.87 \pm 0.24$ \\
$2 \mathrm{hrs}$ & $5.04 \pm 0.54$ & $3.21 \pm 0.32$ & $3.47 \pm 0.07$ & $3.26 \pm 0.06$ & $3.51 \pm 0.06$ \\
$3 \mathrm{hrs}$ & $4.54 \pm 0.76$ & $3.23 \pm 0.93$ & $3.23 \pm 0.11$ & $3.79 \pm 0.20$ & $3.44 \pm 0.01$ \\
$4 \mathrm{hrs}$ & $4.27 \pm 0.40$ & $3.63 \pm 0.49$ & $3.71 \pm 0.01$ & $3.20 \pm 0.02$ & $3.23 \pm 0.11$ \\
$5 \mathrm{hrs}$ & $3.66 \pm 0.04$ & $2.99 \pm 0.09$ & $3.30 \pm 0.13$ & $3.13 \pm 0.01$ & $3.06 \pm 0.09$ \\
Sig & & & $* * *$ & & \\
\hline
\end{tabular}

Note: Mean values bearing different superscripts within rows and columns are significantly different $(\mathrm{p}<0.05)$. L.S $=$ levels of significance. ${ }^{*} \mathrm{NS}=$ not significance.

Table 5: interaction between various levels of lupine extract and storage time on total solid not fat content (\%) of fresh cow’s milk.

\begin{tabular}{lccccc}
\hline Storage time & Control & $\mathbf{0 . 5 \%}$ & $\begin{array}{c}\text { Lupine concentration } \\
\mathbf{1 \%}\end{array}$ & $\mathbf{1 . 5 \%}$ & $\mathbf{2 \%}$ \\
\hline Zero hour & $9.73 \pm 0.69$ & $7.86 \pm 0.74$ & $8.10 \pm 0.01$ & $8.35 \pm 0.25$ & $8.67 \pm 0.28$ \\
$1 \mathrm{hr}$ & $8.93 \pm 0.18$ & $8.20 \pm 0.08$ & $8.17 \pm 0.19$ & $8.52 \pm 0.32$ & $8.10 \pm 0.09$ \\
$2 \mathrm{hrs}$ & $8.49 \pm 0.79$ & $8.90 \pm 0.21$ & $8.57 \pm 0.21$ & $8.50 \pm 0.14$ & $8.50 \pm 0.00$ \\
$3 \mathrm{hrs}$ & $8.39 \pm 0.47$ & $7.93 \pm 0.21$ & $8.65 \pm 0.09$ & $8.94 \pm 0.91$ & $8.60 \pm 0.62$ \\
$4 \mathrm{hrs}$ & $8.52 \pm 0.73$ & $8.18 \pm 0.38$ & $8.01 \pm 0.13$ & $8.18 \pm 0.10$ & $8.45 \pm 0.19$ \\
$5 \mathrm{hrs}$ & $8.61 \pm 0.32$ & $8.55 \pm 0.00$ & $8.28 \pm 0.01$ & $8.72 \pm 0.13$ & $8.74 \pm 0.25$ \\
Sig & & & NS & & \\
\hline
\end{tabular}

Note: Mean values bearing different superscripts within rows are significantly different $\mathrm{p}<0.05)$. L.S $=$ levels of significance. $*$ NS $=$ not significance.

Table 6. Effect of various levels of lupine extract and storage time on $\mathrm{pH}$ of fresh cow's milk

\begin{tabular}{lccccc}
\hline Storage time & Control & $\mathbf{0 . 5 \%}$ & Lupine concentration & $\mathbf{1 . 5 \%}$ & $\mathbf{2 \%}$ \\
\hline Zero hour & $6.78 \pm 0.04$ & $6.79 \pm 0.04$ & $6.72 \pm 0.11$ & $6.81 \pm 0.02$ & $6.79 \pm 0.02$ \\
$1 \mathrm{hr}$ & $6.79 \pm 0.05$ & $7.53 \pm 0.60$ & $6.83 \pm 0.0$ & $6.85 \pm 0.01$ & $6.79 \pm 0.01$ \\
$2 \mathrm{hrs}$ & $6.81 \pm 0.01$ & $6.97 \pm 0.06$ & $6.93 \pm 0.01$ & $6.87 \pm 0.04$ & $6.83 \pm 0.01$ \\
$3 \mathrm{hrs}$ & $6.81 \pm 0.04$ & $7.27 \pm 0.13$ & $7.00 \pm 0.01$ & $6.94 \pm 0.05$ & $6.91 \pm 0.2$ \\
$4 \mathrm{hrs}$ & $6.63 \pm 0.09$ & $6.83 \pm 0.04$ & $6.83 \pm 0.02$ & $6.78 \pm 0.01$ & $6.73 \pm 0.03$ \\
$5 \mathrm{hrs}$ & $6.57 \pm 0.02$ & $6.68 \pm 0.04$ & $6.71 \pm .02$ & $6.67 \pm 0.02$ & $6.71 \pm 0.00$ \\
\hline
\end{tabular}

Note: L.S $=$ levels of significances. $*$ NS $=$ not significance.

The acidity content of the milk samples was not significantly $(p<0.05)$ affected by the various level of lupine extract and storage time. The lowest acidity $(0.20 \pm 0.00 \%)$ was recorded in the milk added with $0.5 \%$ and $1 \%$ lupine extract and stored for zero hours, while the highest one $(0.25 \pm 0.04 \%)$ was found in the milk added with $2 \%$ lupine extract (Table 7) and stored for five hours.
Results in Table 8 show the milk samples' ash content, which was not significantly $(\mathrm{p}<0.05)$ affected by the various level of lupine extract and storage time. The lowest ash content $(0.41 \pm 0.42)$ was reported at two hours of storage in the milk added with zero lupine extract, while the highest one $(0.8 \pm 0.00)$ was found at zero hours of storage and four-hour storage in the milk made of zero lupine extract and $1 \%$ lupine extract. 
Effect of various levels of the lupine extract on Total Bacteria Count of fresh cow's milk

This study explained (Table 9) that significant $(\mathrm{p}<0.05)$ variations were found in the TBC of different treatments. The highest total bacteria count $(6.59 \pm 0.17 \log \mathrm{CFU} / \mathrm{gm})$ was obtained from the control milk samples, while the lowest $(6.46 \pm 0.12 \log \mathrm{CFU} / \mathrm{gm})$ was obtained from the milk sample with $1.5 \%$ of the lupine extract.

\section{Effect of storage time on total bacteria count of raw cow's milk}

This study resulted in full disclosure (Table 10) that the total bacteria count was significantly $(\mathrm{p}<0.05 \log \mathrm{CFU} / \mathrm{gm})$ affected by the storage time. The highest total bacteria count $(6.58 \pm 0.16 \log \mathrm{CFU} / \mathrm{gm})$ was obtained from four hours of storage, while the lowest $(6.44 \pm 0.23 \log$ CFU/gm) was obtained from one-hour storage.

\section{Effect of various levels of lupine extracts and storage time on microbiological characteristics of fresh cow's milk}

This study resulted in full disclosure (Table 11) that the total bacteria count was not significantly $(\mathrm{p}<0.05 \mathrm{log}$ $\mathrm{CFU} / \mathrm{gm}$ ) affected by the level of lupine extract and storage period. The lowest total bacteria count $(6.34 \pm 0.24 \mathrm{log}$ $\mathrm{CFU} / \mathrm{gm}$ ) was recorded at one-hour storage and at the addition of $1 \%$ lupine extract, while the highest one $(6.71 \pm 0.07 \log \mathrm{CFU} / \mathrm{gm})$ was gained from four hours storage in the milk sample containing zero lupine extract (control).

Table 7. Effect of various levels of lupine extract and storage time on titratable acidity content (\%) of fresh cow's milk

\begin{tabular}{|c|c|c|c|c|c|}
\hline \multirow{2}{*}{ Storage time } & \multicolumn{5}{|c|}{ Lupine concentration } \\
\hline & Control & $0.5 \%$ & $1 \%$ & $1.5 \%$ & $2 \%$ \\
\hline Zero hour & $0.23 \pm 0.01$ & $0.20 \pm 0.00$ & $0.20 \pm 0.00$ & $0.22 \pm 0.01$ & $0.22 \pm 0.00$ \\
\hline $1 \mathrm{hr}$ & $0.22 \pm 0.00$ & $0.21 \pm 0.01$ & $0.21 \pm 0.00$ & $0.22 \pm 0.01$ & $0.21 \pm 0.01$ \\
\hline $2 \mathrm{hrs}$ & $0.22 \pm 0.01$ & $0.21 \pm 0.01$ & $0.21 \pm 0.00$ & $0.22 \pm 0.02$ & $0.21 \pm 0.00$ \\
\hline $3 \mathrm{hrs}$ & $0.22 \pm 0.00$ & $0.21 \pm 0.01$ & $0.21 \pm 0.01$ & $0.21 \pm 0.01$ & $0.22 \pm 0.01$ \\
\hline $4 \mathrm{hrs}$ & $0.24 \pm 0.02$ & $0.22 \pm 0.01$ & $0.23 \pm 0.01$ & $0.24 \pm 0.01$ & $0.22 \pm 0.01$ \\
\hline $5 \mathrm{hrs}$ & $0.22 \pm 0.03$ & $0.24 \pm 0.01$ & $0.23 \pm 0.04$ & $0.23 \pm 0.01$ & $0.25 \pm 0.04$ \\
\hline Sig & & & NS & & \\
\hline
\end{tabular}

Note: Mean values bearing different superscripts within rows are significantly different $(\mathrm{p}<0.05)$. L.S = levels of significance. NS = not significance

Table 8. Effect of various levels of lupine extract and storage time on Ash content (\%) of fresh cow's milk

\begin{tabular}{lccccc}
\hline Storage time & Control & $\mathbf{0 . 5 \%}$ & Lupine concentration & $\mathbf{1 0}$ & $\mathbf{1 . 5 \%}$ \\
\hline Zero hour & $0.80 \pm 0.00$ & $0.70 \pm 0.14$ & $0.60 \pm 0.14$ & $0.70 \pm 0.00$ & $0.65 \pm 0.07$ \\
$1 \mathrm{hr}$ & $0.70 \pm 0.07$ & $0.70 \pm 0.00$ & $0.70 \pm 0.00$ & $0.65 \pm 0.07$ & $0.65 \pm 0.21$ \\
$2 \mathrm{hrs}$ & $0.41 \pm 0.42$ & $0.65 \pm 0.07$ & $0.65 \pm 0.07$ & $0.65 \pm 0.07$ & $0.65 \pm 0.07$ \\
$3 \mathrm{hrs}$ & $0.55 \pm 0.07$ & $0.65 \pm 0.07$ & $0.55 \pm 0.07$ & $0.55 \pm 0.07$ & $0.60 \pm 0.00$ \\
$4 \mathrm{hrs}$ & $0.65 \pm 0.07$ & $0.60 \pm 0.00$ & $0.80 \pm 0.00$ & $0.75 \pm 0.07$ & $0.70 \pm 0.14$ \\
$5 \mathrm{hrs}$ & $0.60 \pm 0.00$ & $0.70 \pm 0.14$ & $0.70 \pm 0.07$ & $0.70 \pm 0.00$ & $0.70 \pm 0.00$ \\
Sig & & & NS & & \\
\hline
\end{tabular}

Note:Mean values bearing different superscripts within rows are significantly different $(\mathrm{p}<0.05)$. L.S $=$ levels of significance. $*$ NS $=$ not significance

Table 9. Effect of various levels of the lupine extract on Total Bacteria Count of fresh cow's milk

\begin{tabular}{|c|c|c|c|c|c|c|}
\hline \multirow[b]{2}{*}{ Parameter } & \multicolumn{6}{|c|}{ Lupine concentrations } \\
\hline & Control & $.5 \%$ & $1 \%$ & $1.5 \%$ & $2 \%$ & sig \\
\hline T.B.C & $6.59 \pm 0.17 \mathrm{a}$ & $6.58 \pm 0.18 \mathrm{aa}$ & $6.51 \pm 0.17 \mathrm{ba}$ & $6.46 \pm 0.12 b$ & $6.48 \pm 0.14 \mathrm{~b}$ & $* *$ \\
\hline
\end{tabular}

Note: Mean values bearing different superscripts within rows are significantly different ( $<<0.05)$. L.S = levels of significance. NS = not significance

Table 10. Effect of storage Time on Total Bacteria Count of raw cow's milk

\begin{tabular}{lcccccc}
\hline \multirow{2}{*}{ Bacterial count } & \multicolumn{7}{c}{ Storage time } & \multicolumn{2}{c}{ 3hrs } & 4hrs & 5hrs & sig \\
\hline T.B.C & Zero hr & 1hr & 2hrs & 3hrs
\end{tabular}

Note: Mean values bearing different superscripts within rows are significantly different $(\mathrm{p}<0.05) . *$ L.S $=$ levels of signi ficance. $*$ NS $=$ not significance. 
Table 11. Effect of various levels of lupine extract and storage time on Total Bacteria Count of fresh cow's milk

\begin{tabular}{lccccc}
\hline Storage time & Control & $\mathbf{0 . 5 \%}$ & $\begin{array}{c}\text { Lupine concentration } \\
\mathbf{1 \%}\end{array}$ & $\mathbf{1 . 5 \%}$ & $\mathbf{2 \%}$ \\
\hline Zero hour & $6.52 \pm 0.12$ & $6.63 \pm 0.06$ & $6.55 \pm 0.10$ & $6.43 \pm 0.09$ & $6.49 \pm 0.20$ \\
$1 \mathrm{hr}$ & $6.57 \pm 0.16$ & $6.42 \pm 0.32$ & $6.34 \pm 0.24$ & $6.44 \pm 0.19$ & $6.45 \pm 0.26$ \\
$2 \mathrm{hrs}$ & $6.57 \pm 0.14$ & $6.62 \pm 0.09$ & $6.44 \pm 0.20$ & $6.42 \pm 0.16$ & $6.54 \pm 0.05$ \\
$3 \mathrm{hrs}$ & $6.51 \pm 0.29$ & $6.48 \pm 0.11$ & $6.48 \pm 0.02$ & $6.55 \pm 0.08$ & $6.55 \pm 0.07$ \\
$4 \mathrm{hrs}$ & $6.71 \pm 0.07$ & $6.75 \pm 0.04$ & $6.59 \pm 0.09$ & $6.43 \pm 0.11$ & $6.41 \pm 0.13$ \\
$5 \mathrm{hrs}$ & $6.69 \pm 0.12$ & $6.56 \pm 0.13$ & $6.67 \pm 0.10$ & $6.50 \pm 0.04$ & $6.44 \pm 0.11$ \\
Sig & & & NS & & \\
\hline Nig & & & &
\end{tabular}

Note: Mean values bearing different superscripts within rows are significantly different $(\mathrm{p}<0.05)$. L.S $=$ levels of significance. NS = not significance

\section{Discussion}

\section{Effect of various levels of the lupine extract on the} physicochemical characteristics of fresh cow's milk

The protein of the untreated milk samples had the highest value compared to protein content in other treatments (Table 1). This could be attributed to the high moisture content in the milk samples with various levels of lupine extract, which may decrease the total solids of milk. These results agree with those reported by Wolko et al. (2011). They stated that the lupine extracts deactivate substances such as lectins and protease inhibitors, reducing protein digestion and availability. However, no variations were observed in the protein contents of the milk samples with the lupine extract.

The fat content of the milk samples increased with the increasing level of lupine extract (Table 1). This could be due to the high amount of fat in lupines, which coincided with Kroger's (1971).

The total solids not fat of the milk samples decreased with the increasing level of lupine extract (Table 1). This could be due to the proteolytic activities of lupine extract. These results were not in accordance with Gupta (2010), who studied the compositional change in crossbred and local cow milk, which were affected by 0.3 and $0.5 \%$ formalin preservatives. No significant difference was recorded in lactose, total solids, fat and specific gravity on the addition of formalin in milk.

The $\mathrm{pH}$ of the milk samples showed high values as an increasing level of lupine extract. This could be due to the breakdown of protein as the activity of the lupine extract; these results were not in line with those studied by Giolitti (1949), who found that no changes in lactose, fat, total nitrogen, and $\mathrm{pH}$ after the addition of $0.04 \%$ by weight of $\mathrm{H}_{2} \mathrm{O}_{2}$ to milk.

The acidity and ash contents of the milk samples were not affected by lupine extract addition (Table 1). These results contrasted with those reported by Sandhu et al. (1984).

\section{Effect of storage period on the physicochemical characteristics of fresh cow milk.}

The storage period did not significantly affect this study's protein, total solids, not fat, and ash content (Table $2)$. These results were not in accordance with those reported by ISO (1999), who studied the effect of $\mathrm{C}_{6} \mathrm{H}_{7} \mathrm{KO}_{2}$ (potassium sorbate) on protein content, and it gave the reverse result, i.e., protein content in tested samples that were stored at $4^{\circ} \mathrm{C}$ and $20^{\circ} \mathrm{C}$ increased by $0.20 \%$ and $0.39 \%$, correspondingly.

The fat content (Table 2) increased at zero hours of storage, but it decreased after five hours, which was the lowest one; this was probably due to the lipolytic activities. And these results were in line with the study of Seskena and Janevica (2007).

The PH (Table 2) of the sample with lupine extract was higher at one, two, and three-hour storage than at zero hours of storage. These might be due to the antimicrobial included in the lupines extract, which the lactic acid bacteria inhibited. These results are in line with those of Baltess (1998).

The acidity of raw milk samples showed no increase till four and five hours of storage (Table 2). The increase in acidity might be due to the breakdown of lactose into lactic acid by the lactic acid bacteria. These results are similar to those reported by Minzner and Kroger (1974).

Interaction between the various levels of lupine extract and storage period on the physicochemical characteristics of fresh cow milk

Table 3 showed the results that as the level of lupine extract decreased and the storage period changed, the protein values decreased. These were probably due to the breakdown of protein by the microorganisms in the raw milk sample with the lupine extract. These results agreed with those of Yuan (2001).

Table 4 showed that fat content was significantly $(\mathrm{p}<0.05)$ affected by the levels of lupine extract and storage period. The lowest fat content $(2.99 \pm 0.09 \%)$ was recorded at five hours of storage in the milk without lupine extract, and this might be due to the hydrolysis of fats; the results agreed with those of Kroger (1985).

Total solids not fat content (Table 5), of the milk samples, were not significantly $(p<0.05)$ affected by the levels of lupine extract and storage time. The highest T.N.F content $(9.73 \pm 0.69 \%)$ was for the control milk at zero hours. The decrease in T.S.N.F values was in accordance with the increase in the level of lupine extract and storage time, and these might be due to the moisture content in the extract. These results agreed with those of Boghra and Borkhatriya (2003).

The lowest $\mathrm{pH}(6.57 \pm 0.02)$ was reported at five hours of storage in the milk without lupine extract; these results 
mean the PH values increased as the level of lupine extract increased, and they decreased as the storage time increased, and these might be due to the preservative effect of the lupine extract. These results are in accordance with Baltess (1998), who stated that the important factors influencing the efficiency of preservatives were the initial microbial count in the product, microbial species, temperature, and $\mathrm{pH}$ of the environment.

Table 7 showed the results that the acidity content of the milk samples was not significantly $(\mathrm{p}<0.05)$ affected by the various level of lupine extract and storage time. This might be due to the low activity of antimicrobial factors in lupine extract; these results were not in line with Dawood et al. (1974), who found that an addition of $0.1 \%$ formalin to milk increased the titratable acidity from 0.175 to $0.190 \%$.

Table 8 showed the results that the ash content of the milk samples was not significantly $(\mathrm{p}<0.05)$ affected by the various level of lupine extract and storage time.

\section{Effect of various levels of the lupine extract on total bacteria count of fresh cow's milk}

Table 9 showed that lupine extract significantly $(p<0.05)$ affected the total bacterial count. The effective concentration of lupine extract is $1.5 \%$ to $2 \%$, and the lowest total bacterial count of milk samples with $1.5 \%$ and $2 \%$ lupine extract could be due to the inhibition effect of the lupine extract on the total bacterial count; these results confirmed those of the Sesken and Janevica (2007).

\section{Effect of storage period on total bacteria count of fresh cow's milk}

Table 10 explained that storage time significantly affected the total bacteria count $(\mathrm{p}<0.05)$. The highest total bacteria count $(6.58 \pm 0.16 \log \mathrm{CFU} / \mathrm{gm})$ was reported at four hours of storage, and this agreed with that reported by Erdemoglu et al. (2009).

\section{Interaction between the various level of lupine extract and storage period on total bacteria count of fresh cow's milk}

Table1 1 demonstrated that the total bacteria count was not significantly $(\mathrm{p}<0.05)$ affected by the level of lupine extract and storage time. These might be due to the weak antibacterial effect of the lupine extract. These results were not in line with those reported by Al-Kerwi et al. (2005), who studied the antibacterial effect of milk proteins. This process was mediated by a hydrogen peroxide (H2O2) reaction that was thought to be a major antibacterial substance. Known as milk peroxidase, Lactoperoxidase, in combination with $\mathrm{H}_{2} \mathrm{O}_{2}$ and iodide, produce a potent antibacterial system known as the Lactoperoxidase system.

Based on the result of the study, the following conclusions were drawn: (i) The quality of raw cow's milk was improved with the addition of the lupines extract. (ii) The lupines extract significantly $(\mathrm{p}<0.05)$ affected the protein, fat, total solids, not fat, and $\mathrm{PH}$ contents of raw milk samples. (iii) The storage period significantly $(\mathrm{p}<0.05)$ affected the fat, $\mathrm{PH}$, and acidity but did not significantly affect protein, total solids, not fat, and ash contents of raw milk samples. (iv) The microbiological characteristics of raw milk (total bacteria count) were significantly $(\mathrm{p}<0.05)$ affected by the increasing levels of lupines. (v) The storage period significantly $(p<0.05)$ affected the microbiological characteristics of the fresh milk.

\section{REFERENCES}

Al-Kerwi EA, Al-Hashimi AH, Salman AM. 2005. Mother's milk and hydrogen peroxide. Asia Pac J Clin Nutr 14: 428-431.

AOAC. 2009. Association of Official Analytical Chemists. Food Chem 114 (3): 1141-1146.

Baltess V. 1998. Food Chemistry. 4th ed. University of Latvia, Riga. [Latvian].

Boghra VR, Borkhatriya VN. 2003. Physico-chemical properties and compositional profile of milk samples as affected by formalin preservation- A review. Indian J Dairy Sci 56 (2) 65-71.

Dawood AE, Naghmoush MR, Nofel AA. 1974. The effect of certain additives on acidity and formal number of milk. Ala J Agric Res 22: 73-77.

Dunham JR, Kroger M. 1985. Milk Preservatives. Dairy Herd Improvement, Kansas, USA.

Erdemoglu N, Ozkan S, Duran A, et al. 2009. Analysis and antimicrobial activity of alkaloid extract from Genista vuralii. Pharm Biol 47: 8185.

FOSS Electric. 2005. CombiFossTM 6000FC Operator's Manual. FOSS Electric A/S. 110 p.

Giolitti G. 1949. The effect of high concentrations of hydrogen peroxide on the chemical composition of milk. Atti Soc Ital Sci Vet 3: 543-547.

Gupta HCL, Gupta D. 2010. Compositional change in crossbred and local cow milk as affected by formalin preservative. Pantnagar J Res 8 (2): 219-221.

Hanus O, Gencurova V, Zvackova I. 1992b. Testing Milkofi x, a new preservative preparation for Milk samples used for infrared analysis of milk components. II. Verification of its preservative Effects in relation to infrared analysis. Vet Med 37: 33-43.

Hanus O Gencurova V, Gabriel B, Zvackova I. 1992a. Comparison of the effectiveness of Milkofi $\mathrm{x}$, a preservative preparation, with traditional preservative agents in the determination of somatic Cell count in milk samples using a fluoro-optic-electronic method. Vet Med 37: 91-99.

Heeschen WH, Ubben EH, Rathjen G. 1994. Somatic Cell Counting in Milk: the Use of the Principle of Flow Cytometry for Somatic Cell Counting (Somacount) and Comparison with the Results Obtained with the Fluorescent Optical Principle (Fossomatic 360). Bentley Instruments, Inc., MN.

ISO. 1999. Whole Milk - Determination of Milkfat, Protein, and Lactose Content-Guidance on the Operation of Mid-infrared Instruments. The International Organization for Standardization, Geneva.

Kroger M. 1971. Instrumental milk fat determination. I. Effects of potassium dichromate concentration and sample storage tank on Milko-tester results. J Dairy Sci 54: 735-737.

Kroger M. 1985. Milk sample preservation. J Dairy Sci 68: 783-787.

Minzner RA, Kroger M. 1974. Physicochemical and bacteriological aspects of preserved milk samples and their effect on fat percentage as determined with the Milko-Tester. J Milk Food Technol 37: 123.

$\mathrm{Ng} \mathrm{KF}$, Hayes J F. 1982. Effects of potassium dichromate and sample storage time on fat and protein by Milko-Scan and on protein and casein by a modified Pro-Milk Mk II method. J Dairy Sci 65: 18951899.

Ramakant S. 2006. Production, Processing, and Quality of Milk and Milk Products. FAO, Rome.

Saha BK, Ali MY, Chakraborty M, Islam Z, Hira AK. 2003. Study on the preservation of raw milk with hydrogen peroxide $\left(\mathrm{H}_{2} \mathrm{O}_{2}\right)$ for rural dairy farmers. Pakistan J Nutr 2: 36-42.

Sandhu JS, Nusrath N, Narayanaswamy M, Kanpur OP. 1984. Study on the effect of formalin as preservative on different constituents of raw milk samples during storage. J Food Sci Technol 21 (6): 424-425.

Seskena R, Janevica L. 2007. Influence of chemical preservatives on the quality and composition indices of raw milk samples. Acta Univ Latviensis 723: 171-180.

SPSS. 2007. SPSS v.16.0: Brief Guide. www.spss.com. 
Wolko B, Clements JC, Naganowska B, Nelson MN, Yang H. 2011. Lupines. In: Kole C (ed.). Wild Crop Relatives: Genomic and Breeding Resources. Legume Crops and Forages. Springer, Berlin.
Yuan J. 2001. MAP for shelf - life extension and its synergy with Ozone. Extended shelf life of foods: Quality and Safety Symposium, Seven Oak Brook, IL. 